\title{
The Experience of Our Cardiovascular Surgery Intensive Care in Preoperative False-Negative and Asymptomatic Patients with SARS-COV-2 Infection
}

Etik Kurul Onayı: Ümraniye Eğitim Araştırma Hastanesi Klinik Araştırmalar Etik Kurulu'ndan 14/01/2021 tarih ve B.10.1.TKH.4.34.H.GP.0.01/4 sayı ile etik kurul onayı alınmıştır.

Cıłkar Çatıșması: Çıkar çatıșması bulunmamaktadı.

Finansal Destek: Yoktur.

Hasta Onamı: Hastalardan yazılı onam alınmıștır.
Ethics Committee Approval: Ethics committee approval was obtained from the Clinical Research Ethics Committee of Ümraniye Training and Research Hospital, dated 14/01/2021 and numbered B.10.1.TKH.4.34.H.GP.0.01/4.

Conflict of Interest: There is no conflict of interest.

Funding: None.

Informed Consent: Written informed consent was obtained from all patients.

Cite as: Selçuk I, Güven BB, Selçuk N. Preoperatif yalancı negatif ve asemptomatik olan SARS-COV-2 enfeksiyonlu hastalardaki kardiyovasküler cerrahi yoğun bakım deneyimlerimiz. GKDA Derg. 2021;27(4):254-60.

ÖZ

Amac: Kalp cerrahisi geçiren hastalarda COVID-19'un etkileri hakkında literatürde çok az veri mevcuttur. Bu calısmada amacımız, COVID-19'un kardiyak cerrahi sonrası etkilerini, hastaların temel özelliklerini ve laboratuvar bulgularını tanımlamaktır. Aynı zamanda preoperatif süreçte rRT-PCR'nin zayıf tanı performansının altında yatan mekanizmayı tartışmaktır.

Yöntem: Erişkin kalp cerrahisi kliniğimizde 18 Mayıs 2020 - 07 Haziran 2021 tarihleri arasında ameliyat edilen 191 hastanın verileri geriye dönük olarak incelendi. Ameliyat öncesi asemptomatik ve rRT-PCR (-) olan ve ameliyat sonrası rRT-PCR pozitifleșen toplam 12 hasta çalıșmaya dahil edildi. Acil operasyon gerektiren, preoperatif dönemde $r R T-P C R$ çalışmamıs veya $r R T-P C R(+)$ olan, günübirlik cerrahi operasyon geçirenler ile entübe edilmeden opere edilen hastalar çalışmaya dahil edilmedi. Hastaların yaş, cinsiyet, tanı, yapılan operasyon, YBÜ yatış süreleri, entübasyon süreleri, ekokardiyografi, kan gazı ve biyokimya sonuçları ile PCR sonuçları kaydedildi.

Bulgular: Calısmada 87 hastadan postoperatif rRT-PCR calısıldı ve 12 (\%13.8) hastada sonuc (+) geldi. 12 hastadan 2'si (\%16.7) SARS-CoV-2 pnömonisi nedeniyle ex oldu. Preoperatif lökosit $\left(7.7810^{3} / \mathrm{mcl}\right)$, lenfosit $\left(1.5210^{3} / \mathrm{mcL}\right)$ ve CRP $(49.27 \mathrm{mg} / \mathrm{L})$ değerlerinin ortalaması normal değer aralığında iken, ferritin (823 ng/ $\mathrm{ml}$ ) ve D-Dimer $(1138 \mathrm{ng} / \mathrm{ml}$ ) değerlerinin ortalaması normal değer aralığının üzerinde bulundu. Preoperatif ve postoperatif $\mathrm{PaO} / \mathrm{FiO}_{2}$ oranlarındaki değişkenlik ex olan hastalarda (ortalama: $40,50 \pm 4,94$ ) sağkalan hastalarınkine (ortalama: $16,4 \pm 9,37)$ oranla daha yüksek bulundu $(P=0.053)$.

Sonuc: Ekstrakorporeal dolașımın kendisinin sistemik bir inflamatuar yanıta neden olarak COVID-19 tablosunu şiddetlendirebileceği unutulmamalıdır. Aynı zamanda daha az yalancı negatiflik PCR sonuçları görmek için, kardiyak cerrahiye girecek olan hastalara operasyon öncesi en az 7 gün izolasyon ve SARS-Cov-2 için PCR örneklerinin mümkün olduğunca alt solunum yollarından alınmasını önermekteyiz

Anahtar kelimeler: coronavirus, COVID-19, SARS-CoV-2, kalp cerrahisi

ABSTRACT

Objective: There is little data in the literature on the effects of COVID-19 in patients undergoing cardiac surgery. Our aim in this study is to describe the post-cardiac surgical effects of COVID-19, the basic characteristics of the patients and their laboratory findings; and also to discuss the mechanism underlying the poor diagnostic performance of $r R T-P C R$.

Methods: The data of 191 patients who were operated between 18 May 2020-07 June 2021 were retrospectively analyzed. A total of 12 patients who were asymptomatic and $r R T-P C R$ (-) preoperatively and $r R T-P C R$ positive postoperatively were included. Patients who required emergency operation, did no perform rRT-PCR in the preoperative period or had rRT-PCR (+), had outpatient surgery were not included. The patients' age, operation, length of stay in the ICU, intubation times, echocardiography, blood gas and biochemistry results and PCR results were recorded.

Results: In the study, postoperative rRT-PCR was studied from 87 patients and the result was (+) in 12 (13.8\%) patients. Two of $12(16.7 \%)$ patients died due to SARS-CoV-2 pneumonia. While the mean values of preoperative leukocytes $\left(7.7810^{3} / \mathrm{mcL}\right)$, lymphocytes $\left(1.5210^{3} / \mathrm{mcL}\right)$ and $C R P(49.27 \mathrm{mg} / \mathrm{dL})$ were within the normal range, the mean values of ferritin $(823 \mathrm{ng} / \mathrm{ml})$ and D-Dimer $(1138 \mathrm{ng} / \mathrm{ml})$ were above the normal range.

Conclusion: We recommend that patients has to be isolated for at least 7 days before the operation. Also sputum samples from the tracheal tube should be studied simultaneously nasopharyngeal PCR samples in the preoperative and the early postoperative period in order to minimize false negative PCR results.
Received/Geliş: 20.08 .2021

Accepted/Kabul: 03.09.2021

First Published: 21.09.2021

Nehir Selçuk

Sultanabdülhamid Han Eğitim ve Araştrrma Hastanesi, Kalp ve Damar Cerrahisi

Anabilim Dalı

İstanbul, Türkiye

nehirtandogar@gmail.com

ORCiD: 0000-0003-0364-7654

i. Selçuk 0000-0001-6334-9881 Sultanabdülhamid Han Eğitim ve Araștırma Hastanesi, Anestezi Anabilim Dalı istanbul, Türkiye

B. B. Güven 0000-0002-3628-7408 Dr Siyami Ersek Eğitim ve Araştrrma Hastanesi, Kalp ve Damar Cerrahisi

Anabilim Dalı istanbul, Türkiye

(C) Telif hakkı Göğüs Kalp Damar Anestezi ve Yoğun Bakım Derneği'ne aittir. Logos Tıp Yayıncılık tarafindan yayınlanmaktadır Bu dergide yayınlanan bütün makaleler Creative Commons Atf-Gayri Ticari 4.0 Uluslararası Lisansı ile lisanslanmıştr.

(c) Copyright The Society of Thoracic Cardio-Vascular Anaesthesia and Intensive Care. This journal published by Logos Medical Publishing. Licenced by Creative Commons Attribution-NonCommercial 4.0 International (CC BY) 
i. Selçuk ve ark., Preoperatif Yalancı Negatif ve Asemptomatik Olan SARS-COV-2 Enfeksiyonlu Hastalardaki Kardiyovasküler Cerrahi Yoğun Bakım Deneyimlerimiz

\section{Giriş}

Şiddetli akut solunum sendromu koronavirüs-2 (SARS-CoV-2) ilk olarak 2019 yılı Aralık ayında tanımlanmış ve virüs dünya genelinde hızla yayılarak coronavirus hastalığı-2019 (COVID-19) pandemisine neden olmuştur. Birçok kalp cerrahisi merkezinde olduğu gibi solunum cihazı ve yoğun bakım ihtiyacının fazla olduğu bu süreçte kalp cerrahisi merkezimiz COVID-19 yoğun bakım ünitesine dönüştürülmüştür. Sağıık çalışanlarımızın aşılanması ile birlikte tekrardan elektif kalp cerrahisi vakaları alınmaya başlanmıştır. Küresel çapta COVID-19 aşılama çalışmaları hızla devam etmesine rağmen henüz pandemi sonlanmamıştır. Ülkemizde de 18 yaş üstü nüfusun yarısından fazlası çift doz aşılanmasına rağmen pandemiden kaynaklı ölümler halen devam etmektedir ${ }^{[1]}$.

Kalp cerrahisi geçiren hastalarda COVID-19'un etkileri hakkında literatürde çok az veri mevcuttur. Pandemi sırasında kalp cerrahisi gerektiren hastalar için rehber niteliğinde kesin öneriler de mevcut değildir. Ancak ortak görüş, elektif kalp cerrahisi planlanan bir hastanın pozitif olma riskini azaltmak için, planlanan ameliyat tarihine yakın bir zamanda (tercihen $<48$ saat), yalnızca nazofaringeal sürüntü örneklerinden gerçek zamanlı revers transkriptaz-polimeraz zincir reaksiyonu (rRT-PCR) kullanılarak viral RNA tespiti yapılmasının yeterli olduğudur ${ }^{[2]}$. Bizim merkezimizde buna ek olarak operasyondan hemen sonra entübe olarak yoğun bakım ünitesi (YBÜ)'ne alınan hastalarda endotrakeal tüp içerisinden alınan balgam örneklerinden de rRT-PCR çalışılmaktadır. Bu şekilde preoperatif $r R T-P C R$ sonucu negatif olan 12 hastada postoperatif dönemde kalp damar cerrahisi YBÜ'de tüp içerisinden alınan balgam örneklerinde pozitif sonuç tespit edilmiştir.

Bu çalışmada amacımız COVID-19'un bu hastaların ameliyat sonrası seyrine etkisini, hastaların temel özelliklerini ve laboratuvar bulgularını tanımlamaktır. Aynı zamanda preoperatif süreçte rRT-PCR'nin zayıf tanı performansının altında yatan mekanizmayı tartışmaktır.

\section{GEREÇ ve YÖNTEM}

Çalışmamız retrospektif, tek merkezli bir vaka serisi çalışmasıdır. Ümraniye Eğitim Araştırma Hastanesi
Klinik Araştırmalar Etik Kurulu'ndan 14/01/2021 tarih ve B.10.1.TKH.4.34.H.GP.0.01/4 sayı ile etik kurul onayı alınmıştır.

Kalp ve damar hastalıkları nedeniyle elektif olarak ameliyatı planlanan, ameliyat öncesi asemptomatik ve rRT-PCR negatif olan, ameliyat sonrası rRT-PCR pozitifleşen hastalar çalışmaya dahil edildi. Acil operasyon gerektiren, preoperatif dönemde rRT-PCR çalışmamış veya rRT-PCR pozitif olan, günübirlik cerrahi operasyon geçirenler ile entübe edilmeden opere edilen hastalar çalışmaya dahil edilmedi. Hastaların yaş, cinsiyet, tanı, yapılan operasyon, YBÜ yatış süreleri, entübasyon süreleri, ekokardiyografi, arter kan gazı (AKG) ve biyokimya sonuçları ile PCR sonuçları kaydedildi. Hastaların preoperatif $\mathrm{PaO}_{2} /$ $\mathrm{FiO} 2$ değerleri, operasyon salonunda entübe edildikten sonraki ilk ölçülen AKG değerlerinden hesaplandı. Postoperatif $\mathrm{PaO}_{2} / \mathrm{FiO}_{2}$ değerleri ise operasyon bittikten sonra YBÜ'de ilk ölçülen AKG değerlerinden hesaplandı.

Tüm hastalardan ve refakatçilerinden operasyondan önceki 48 saat içerisinde nazofarengeal sürüntü rRTPCR örnekleri alındı. Hastalardan ayrıca preoperatif rutin tetkikler ve enfeksiyöz belirteçler (C-reaktif protein, lökosit, lenfosit, ferritin) için kan örnekleri alındı. Aynı zamanda operasyondan önceki bir hafta içerisinde tüm hastalardan posteroanterior akciğer grafi (PAAG)'leri istendi. Operasyondan 1 gün önce hastalar, istenen tüm laboratuvar ve görüntüleme sonuçları ile birlikte anestezi hekimi tarafından temas öyküsü sorgulanarak değerlendirildi. Temas hikayesi olan hastalara iki hafta sonra rRT-PCR tekrarı ile birlikte ileri tarihe operasyon günü verildi. Tüm hastalar sadece bir refakatçi kalması koşulu ile tek kişilik odalarda takip edildiler ve refakatçi dışında kliniğe hasta ziyaretçileri kabul edilmedi. Genel anestezi alarak operasyona alınan tüm hastalar kalp damar cerrahisi YBÜ'de ekstübe edildiler ve ekstübe edilmeden önce hepsinden endotrakeal tüp içerisinden balgam örneği alınarak rRT-PCR çalışıldı. COVID-19 PCR testi sonucu pozitif çıkan hastalardan YBÜ'de ekstübe edilmiş olanlar COVID servisine transfer edilirken, entübe olanlar ise COVID YBÜ'ye transfer edildiler. Bu hastaların tedavilerine transfer edildikleri yerde enfeksiyon hastalıkları kontrolünde devam edildi ve bu süreçte toraks bilgisayarlı tomografi (BT) görüntüleri çekilerek pulmoner tutulum açısından incelendi. 
İstatistik: Çalışmada hasta sayısı düşük olduğundan dolayı istatistiksel analizler için tanımlayıcı istatistikler (ortalama, standart sapma, sıklık, oran, minimum, medyan, maksimum) kullanıldı.

\section{BULGULAR}

Mayıs 2020-Haziran 2020 tarihleri arasında kliniğimizde kardiyovasküler hastalıkları nedeniyle toplam 191 hasta opere edildi. Acil olarak opere edilen 24 hastanın dışındaki tüm hastalar COVID-19 açısından asemptomatik olarak kliniğe kabul edildiler. Günübirlik cerrahi operasyon (kronik venöz yetmezlik, port takılması, A-V fistül açılması) geçiren 46 hasta ile entübe edilmeden opere (stent uygulamaları, embolektomi, karotis endarterektomi, kronik venöz yetmezlik) edilen 34 hasta çalışma dışı bırakıldı. Toplam 87 hasta ameliyathaneden YBÜ'ye entübe olarak alındı ve trakeal tüp içerisinden alınan balgam örneklerinde rRT-PCR çalışıldı. 75 hastanın rRT-PCR sonucu negatif iken, 12 (\%13.8) hastada sonuç pozitif geldi (Şekil 1).

Elektif olarak genel anestezi altında operasyona alınan ve postoperatif COVID-19 PCR testi sonucu pozitif gelen 12 hastaya; koroner arter bypass greft ( $n: 5)$, iliyak arterlere stent uygulaması (n:2), femoropopliteal bypass ( $n: 1)$, BENTALL prosedürü $(n: 1)$, intrakardiyak tümör eksizyonu ( $\mathrm{n}: 1)$, endovasküler anevrizma onarımı $(n: 1)$ ve EKOS ile endarterektomi $(n: 1)$ operasyonları gerçekleştirildi (Tablo 1). Operasyonların hiçbirinde peroperatif cerrahi komplikasyon gözlenmedi. Postoperatif dönemde hastaların hepsine toraks BT görüntülemesi yapıldı ve 2 hastada COVID19 pnömonisi ile uyumlu buzlu cam dansiteleri izlendi (Tablo 1). 12 hastadan toraks BT de tutulum tespit

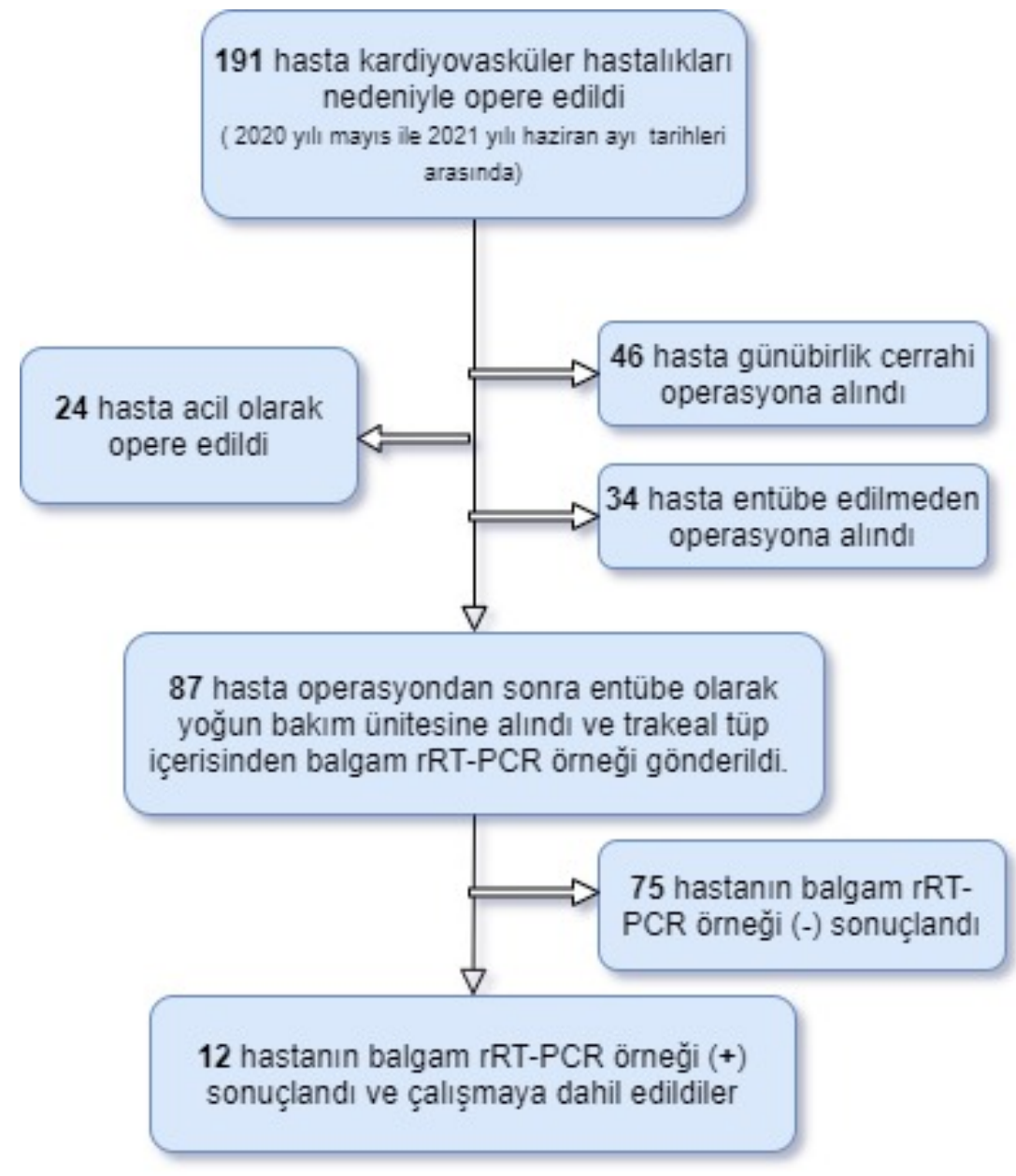

Şekil 1. Retrospektif çalışmanın akış şeması. 


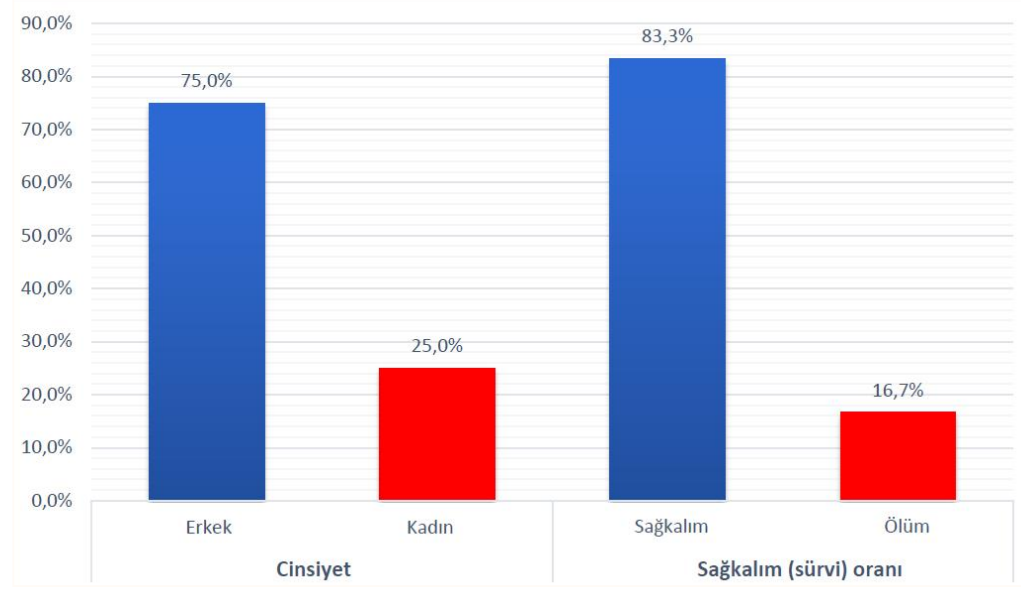

Ş̧ekil 2. Vakaların cinsiyet ve sağkalım (sürvi) oranları.

\section{Tablo 1.COVID-19 hastalarının ameliyat bilgileri ile postoperatif görüntüleme ve ameliyat sonrası sonuçları.}

\begin{tabular}{|c|c|c|c|c|c|}
\hline Yaş & Cinsiyet & Tanı & $\begin{array}{l}\text { Uygulanan } \\
\text { Operasyon }\end{array}$ & $\begin{array}{c}\text { Toraks BT'de } \\
\text { buzlu cam görünümü }\end{array}$ & Sağkalım \\
\hline 36 & $\mathrm{E}$ & $\begin{array}{c}\text { Asendan aort anevrizması, } \\
\text { Aort stenozu }\end{array}$ & BENTALL Prosedürü & - & Sağkalım \\
\hline 72 & $\mathrm{E}$ & Abdominal aort anevrizması & Endovasküler anevrizma onarımı & - & Sağkalım \\
\hline 55 & $\mathrm{E}$ & Periferik arter hastalığı & Sol iliak artere balon expandable stent & - & Sağkalım \\
\hline 70 & K & $\begin{array}{l}\text { Sağ karotis ve subkalvian arter } \\
\text { trombozu, pulmoner emboli }\end{array}$ & EKOS + Endarterektomi & - & Sağkalım \\
\hline 49 & K & İntrakardiyak tümör & İntrakardiyak tümör eksizyonu & - & Sağkalım \\
\hline 55 & E & Koroner arter hastalığı & Koroner arter baypas greft & - & Sağkalım \\
\hline 60 & $\mathrm{E}$ & Periferik arter hastalığı & $\begin{array}{l}\text { Sağ ve sol iliak artere kissing balon } \\
\text { expandable stent }\end{array}$ & - & Sağkalım \\
\hline 60 & $\mathrm{E}$ & Koroner arter hastalığı & Koroner arter baypas greft & - & Sağkalım \\
\hline 57 & $\mathrm{E}$ & Koroner arter hastalığı & Koroner arter baypas greft & - & Sağkalım \\
\hline 65 & E & Periferik arter hastalığı & Sağ femoropopliteal baypass & - & Sağkalım \\
\hline 65 & $\mathrm{E}$ & Koroner arter hastalığı & Koroner arter baypas greft & + & Ölüm \\
\hline 66 & K & Koroner arter hastalığı & Koroner arter baypas greft & + & Ölüm \\
\hline
\end{tabular}

K: Kadın , E: Erkek, BT: Bilgisayarlı Tomografi , EKOS: EkoSonik endovasküler sistem

edilen 2 hasta COVID-19, YBÜ'nde SARS-CoV-2 pnömonisi nedeniyle ex oldu (Şekil 2).

Hastaların yaşı 36 ile 72 yıl ve ortalaması 59.17'idi. Hastaların \%25'i kadın, \%75'i de erkekti (Şekil 2).
Preoperatif sol ventrikül ejeksiyon fraksiyon (SVEF)' larından en düşük olanı \%45'ti ve hastaların SVEF genel ortalaması \%49.58'di.

Hastaların preoperatif lökosit değerleri 3.71 ila 15.07 
Tablo 2. COVID-19 hastalarının perioperatif klinik ve laboratuvar özellikleri.

\begin{tabular}{lccccc} 
& Ortalama & Standart sapma & Minimum & Medyan & Maksimum \\
\hline Yaş & 59.17 & 9.90 & 36.00 & 60.00 & 72.00 \\
$\mathrm{SVEF}(\%)$ (preop) (N:50-70) & 49.58 & 3.96 & 45.00 & 50.00 & 60.00 \\
$\mathrm{PaO}_{2} / \mathrm{FiO}_{2}$ (preop.) (N >200) & 238.75 & 84.14 & 145.00 & 254.00 & 435.00 \\
$\mathrm{PaO}_{2} / \mathrm{FiO}_{2}$ (postop.) (N >200) & 218.33 & 88.05 & 108.00 & 226.50 & 420.00 \\
$\mathrm{Entübasyon} \mathrm{süresi} \mathrm{(saat)}$ & 28.33 & 41.17 & 8.00 & 16.00 & 158.00 \\
YBÜ yatış süresi (gün) & 3.25 & 5.05 & 1.00 & 1.50 & 14.00 \\
Lökosit $\left(10^{3} / \mathrm{mcL}\right)($ preop) (N:3.6-11) & 7.78 & 3.18 & 3.71 & 7.25 & 15.07 \\
Lenfosit $\left(10^{3} / \mathrm{mcL}\right)($ preop)(N:1.5-3.5) & 1.52 & .63 & .39 & 1.60 & 2.23 \\
Ferritin (ng/ml) (preop) (N:20-500) & 823.25 & 790 & 160 & 627 & 2815 \\
D-Dimer (ng/ml) (preop) (N:0-0.5) & 1138 & 2624 & 1.00 & 335 & 9300 \\
CRP (mg/dL) (preop) (N <50) & 49.27 & 38.40 & 2.00 & 41.15 & 118 \\
\hline
\end{tabular}

SVEF: Sol ventrikül ejeksiyon fraksiyonu, YBÜ: Yoğun bakım ünitesi, Preop.: Preoperatif, Postop.: Postoperatif, CRP: C-Reaktif Protein, N:Normal

$10^{3} / \mathrm{mcL}$ arasında değişmekteydi ve ortalama 7.78 $10^{3} / \mathrm{mcL}^{\prime}$ idi. Preoperatif lenfosit değerleri 0.39 ila $2.2310^{3} / \mathrm{mcL}$ arasında değişmekteydi ve ortalama $1.5210^{3} / \mathrm{mcL}^{\prime}$ idi. Preoperatif ferritin değerleri 160 ila $2815 \mathrm{ng} / \mathrm{ml}$ arasında değişmekteydi ve ortalama $823.25 \mathrm{ng} / \mathrm{ml}$ 'idi. Preoperatif D-Dimer değerleri 1.0 ila $9300 \mathrm{ng} / \mathrm{ml}$ arasında değişmekteydi ve ortalama 1138 ng/ml'idi. Preoperatif C-Reaktif Protein (CRP) değerleri 2.0 ila $118 \mathrm{mg} / \mathrm{dL}$ arasında değişmekteydi ve ortalama $49.27 \mathrm{mg} / \mathrm{dL}$ 'idi (Tablo 2). Preoperatif lökosit, lenfosit ve CRP değerlerinin ortalaması normal değer aralığında iken, ferritin ve D-Dimer değerlerinin ortalaması normal değer aralığının üzerindeydi.

Hastaların YBÜ'de yatış süreleri ortalama $3.25 \pm 5.05$ gün ile 1 ila 14 gün arasında değişiyordu. Entübe kaldıkları sürenin ortalaması ise $28.33 \pm 41.17$ saat olup, 8 ila 158 saat arasında değişmekteydi (Tablo 2). En uzun yatış ve entübasyon süreleri COVID-19 pnömonisi nedeniyle ex olan 2 hastaya aitti.

Entübe edilerek ventilatöre bağlanan hastaların oksijenizasyonunu değerlendirmek için kullanılan $\mathrm{PaO2} /$ $\mathrm{FiO}_{2}$ oranı $(\mathrm{N}>200)$ preoperatif dönemde ortalama $238.75 \pm 84.14$ idi ve en düşük değer 145 idi. Postoperatif dönemde ise ortalama $218.33 \pm 88.05$ idi ve en düşük değer 108 idi (Tablo 2).

\section{TARTIŞMA}

2019 yılı aralık ayından günümüze kadar kesintisiz bir şekilde etkisini sürdürmeye devam eden SARS-CoV-2 virüsü hakkında, halen çözümlenememiş birçok bilin- meyen vardır. SARS-CoV-2 virüsü hem mutasyonları hem de her hastadaki farklı seyri nedeniyle klinisyenlerin kafasını karıştırmaya devam etmektedir. Çalışmamızda ameliyat öncesi dönemde rRT-PCR negatif, asemptomatik olan ve postoperatif süreçte balgam örneğinde COVID-19 rRT-PCR pozitifliği açığa çıkan 12 hastanın klinik özelliklerini ve laboratuvar bulgularını retrospektif olarak inceledik.

COVID-19 tanısı alan hastalar asemptomatik taşıyıcı olabilir veya hafif semptomlardan solunum veya çoklu organ yetmezliğine kadar değişen semptomlar geliştirebilirler ${ }^{[3]}$. Hastalar çoğunlukla nefes darlığı, ateş, öksürük, miyalji ve halsizlik ile başvururlar. Daha az görülen semptomlar arasında ishal, karın ağrısı, baş dönmesi, öksürük, plöritik göğüs ağrısı ve hemoptizi bulunur ${ }^{[4,5]}$. Çalışma grubumuzda yer alan hastaların hiçbirinde yeni gelişmiş bir organ yetmezliğine ve bu semptomlara preoperatif dönemde rastlamadık. Postoperatif süreçte ise bu semptomların birçoğu, ameliyat sonrası hastalarda normal olarak görülebilen semptomlar olduğu için, COVID-19 tanısında klinisyenler olarak en fazla rRT-PCR'a güvenmek durumundayız.

Viral RNA tespiti için kullanılan rRT-PCR testi hem üst hem de alt solunum yolundan alınan örneklerden çalışılmaktadır. Ancak bazı yazarlar üst solunum yolundan alınan örneklerde ortalama \%38'e varan oranlarda yalancı negatif rRT-PCR sonuçlarının alınabildiğini bildirmiştir. $[6,7]$ Yang ve ark. ${ }^{[8]}$ yaptıkları bir araştırmada COVID-19 hastalarında en yüksek PCR pozitiflik oranını balgam örneklerinde (\%82) göster- 
i. Selçuk ve ark., Preoperatif Yalancı Negatif ve Asemptomatik Olan SARS-COV-2 Enfeksiyonlu Hastalardaki Kardiyovasküler Cerrahi Yoğun Bakım Deneyimlerimiz

mişler, bunu daha az oranda nazofaringeal sürüntüler (\%62) izlemiş ve en az pozitif sonucu orofaringeal sürüntü (\%53) örneklerinde göstermişlerdir. Ancak, çalışmalar COVID-19 vakalarının yalnızca küçük bir bölümünün balgam üretimi $(\% 28-\% 33,7)$ gösterdiğini bildirmektedir. Bu nedenle günümüzde halen nazofaringeal sürüntüler, COVID-19'un laboratuvar teşhisi için en yaygın olarak uygulanabilir numuneler olarak hizmet etmektedir. Biz kliniğimizde rutin olarak ameliyathane ortamını kirletmemek adına entübe edilen operasyon hastalarını YBÜ'de ekstübe etmekteyiz ve ekstübe etmeden önce de trakeal tüp içerisinden rRT-PCR çalışılması için balgam örneği gönderiyoruz. Aynı zamanda bu çalışmada elde ettiğimiz bulgulardan sonra, kliniğimizde yeni bir uygulama olarak preoperatif süreçte balgam örneği verebilen hastaların balgam numunelerinden de PCR çalışmaktayız. Preoperatif süreçte balgam örneği verebilen hasta sayısı az olabilir, ancak bu hastalarda PCR pozitifliğinin tespit edilmesi, peroperatif morbidite ve mortalite açısından önemlidir.

SARS-CoV-2 virüsünün kuluçka süresi ortalama 5,2 gün olmak üzere 14 güne kadar ulaşabilmektedir. Bir asemptomatik taşıyıcının kuluçka süresi 19 gün olup hemen hemen tüm hastaların temastan sonraki 12 gün içinde bir veya daha fazla semptom yaşaması muhtemeldir ${ }^{[4]}$. Özellikle tipik semptom başlangıcından (5. gün) önceki 4 günlük enfeksiyonda, enfekte bir kişide yanlış negatif sonuç olasılı̆̆ı 1. günde $\% 100$ iken bu oran azalarak 8. günde \%20'ye kadar düştüğü rapor edilmiştir ${ }^{[7]}$. Bu nedenle preoperatif süreçte yalancı negatif rRT-PCR sonuç oranlarını düşürmek için operasyona alınacak olan hastaların PCR örneği vermeden önceki 1 haftalık süreçte kendilerini izole etmiş olmaları büyük önem taşımaktadır. Aksi takdirde test örneği vermeden birkaç gün önce gerçekleşen temaslarda, yalancı negatif rRT-PCR sonucu elde etme ihtimalinin çok yüksek (\%100) olduğu görülmektedir. Bizim çalışma grubumuzda yalancı negatif PCR test oranımı \%13.8 idi. Bu oranın literatüre göre düşük olmasının muhtemel nedeni, vakaların hepsinin elektif olarak alınması ve operasyon tarihinden en az 10 gün önce hasta-hekim görüşmesi esnasında hastalara COVID-19 hastalığına yönelik izolasyon tedbirlerinin anlatılmasıdır.

COVID-19 hastalarında birçok araştırmacı lenfopeni ile hastalığın şiddeti arasında bir korelasyon olduğu- nu bildirmiştir ${ }^{[9-11]}$. Aynı şekilde D-Dimer yüksekliği ile akut inflamatuar belirteçlerden ferritin ve CRP yüksekliğinin de genellikle hastalığın şiddetli seyrettiği olgularda hafif vakalara göre daha fazla olduğu varsayılmaktadır ${ }^{[12-14]}$. Çalışma grubumuzdaki hastalarda preoperatif lökosit, lenfosit ve CRP değerleri normal değer aralığında iken, ferritin ve D-Dimer değerlerinin ortalaması normal değer aralığının üzerindeydi. Hastaların preoperatif asemptomatik olmaları nedeniyle lökosit, lenfosit ve CRP değerlerinde anormallik görülmemiştir. Çalışmadaki preoperatif ferritin ve D-Dimer yüksekliği ise COVID-19'dan bağımsız olarak kardiyovasküler patolojisi olan erişkin hastalarda, mevcut komorbiditeleri (anemi, demir ilacı kullanı$\mathrm{m}$, pulmoner emboli, tromboemboli gibi) nedeniyle eş zamanlı olarak beklenebilen bir durumdu.

COVID-19'un kalp cerrahisi geçiren hastalar üzerindeki etkisi hakkında bilgilerimiz çok kısıtıdır. Fattouch ve ark. ${ }^{[15]}$ kalp cerrahisi sonrası COVID-19 tespit ettikleri 20 hastalarının sonuçlarını yayınladılar ve mortaliteyi \%15 (3/20) olarak açıkladılar. Aynı raporda, kalp cerrahisi sırasında ekstrakorporeal dolaşımın sistemik inflamatuar bir yanıt ortaya çıkarabileceğini ve bu durumun COVID-19 hastalığını şiddetlendirebileceğini öne sürmüşlerdir. Benzer şekilde bizim çalışmamızda da mortalite oranımız \%17 olup, mortalitenin gerçekleştiği 2 hastaya da kardiyak cerrahi için ekstrakorporeal dolaşım uygulanmıştır. Toplamda çalışmadaki hastaların sadece 7'sine operasyon sırasında ekstrakorporeal dolaşım uygulanmıştır. Hastalarımızın hepsinin ekstrakorporeal dolaşım almamış olmasının sürvi açısından olumlu etki yapmış olabileceğini düşünüyoruz, ancak yetersiz vaka sayısı nedeniyle bu durumu istatistiksel olarak değerlendiremedik. Bu nedenle bu çalışmanın en önemli kısıtlılığı küçük örneklem büyüklüğüdür.

Sonuç olarak, COVID 19 pandemi sürecinde hem hastalığın erken evresinde hem de örnek alım yerinden kaynaklı yalancı negatif PCR sonuçları çıkmaktadır. Bu nedenle yalancı negatif PCR sonuçlarını minimalize etmek için hastaların operasyon öncesi en az 7 gün izolasyonunu, preoperatif nazofarengeal PCR örnekleri ile eş zamanlı ve postoperatif erken dönemde trakeal tüp içinden balgam örneklerinin de çalışılmasını önermekteyiz. Böylece pandemide hem hastane kaynaklı bulaşın hem de peroperatif morbidite ve mortalitenin azalacağını düşünmekteyiz. 


\section{KAYNAKLAR}

1. T.C. Sağlık Bakanlığı, COVID-19 aşısı bilgilendirme platformu. https://covid19asi.saglik.gov.tr (Erişim tarihi: 14 Ağustos 2021).

2. Al-Balas $\mathrm{M}, \mathrm{Al}$-Balas $\mathrm{HI}, \mathrm{Al}-\mathrm{Balas} \mathrm{H}$. Surgery during the COVID-19 pandemic: A comprehensive overview and perioperative care. Am J Surg. 2020;219(6):903-6. https://doi.org/10.1016/j.amjsurg.2020.04.018

3. Bai Y, Yao L, Wei T. Presumed asymptomatic carrier transmission of COVID-19. J Am Med Assoc. 2020;323(14):1406-1407. https://doi.org/10.1001/jama.2020.2565

4. Wang D, Hu B, Hu C. Clinical characteristics of 138 hospitalized patients with 2019 novel coronavirus-infected pneumonia in wuhan, China. J Am Med Assoc. 2020;323(11):1061-9. https://doi.org/10.1001/jama.2020.1585

5. Harky A, Chen R, Pullan M. Examining the impact of COVID-19 on cardiac surgery services: The lessons learned from this pandemic. Journal of Cardiac Surgery. 2020;35:2364-6. https://doi.org/10.1111/jocs.14783

6. Engelman DT, Lother S, George I, Funk DJ, Ailawadi G, Atluri $P$ et al. Adult cardiac surgery and the COVID-19 pandemic: Aggressive infection mitigation strategies are necessary in the operating room and surgical recovery. Journal of Thoracic and Cardiovascular Surgery. 2020;160(2):447-451. https://doi.org/10.1016/j.jtcvs.2020.04.059

7. Kucirka LM, Lauer SA, Laeyendecker O, Boon D, Lessler J. Variation in False-Negative Rate of Reverse Transcriptase Polymerase Chain Reaction-Based SARSCoV-2 Tests by Time Since Exposure. Annals of Internal Medicine. 2020;173(4):262-267. https://doi.org/10.7326/M20-1495

8. Yang $\mathrm{Y}$, Yang $\mathrm{M}$, Yuan J, Wang $\mathrm{F}$, Wang Z, Li J et al. Laboratory Diagnosis and Monitoring the Viral Shedding of SARS-CoV-2 Infection. The Innovation. 2020;1:1-6. https://doi.org/10.1016/j.xinn.2020.100061

9. Zheng M, Gao Y, Wang G, Song G, Liu S, Sun D, et al. Functional exhaustion of antiviral lymphocytes in COVID-19 patients. Cell Mol Immunol. 2020;17:533-5. https://doi.org/10.1038/s41423-020-0402-2

10. He Z, Zhao C, Dong Q, Zhuang H, Song S, Peng G, et al. Effects of severe acute respiratory syndrome (SARS) coronavirus infection on peripheral blood lymphocytes and their subsets. Int J Infect Dis. 2005;9:32330. https://doi.org/10.1016/j.ijid.2004.07.014

11. Tan L, Wang Q, Zhang D, Ding J, Huang Q, Tang YQ, et al. Lymphopenia pre- dicts disease severity of COVID19: a descriptive and predictive study. Signal Transduct Target Ther. 2020;5:33. https://doi.org/10.1038/s41392-020-0148-4

12. Porto LC, Costa CH, Nunes AS, Bouzas I, Ferreira TF, Porto VM, et al. Clinical and laboratory characteristics in outpatient diagnosis of COVID-19 in healthcare professionals in Rio de Janeiro, Brazil. J Clin Pathol 2021. (In Press) https://doi.org/10.1136/jclinpath-2020-206797

13. Zhao D, Yao F, Wang L, Zheng L, Gao Y, Ye J, et al. Acomparative study on the clinical features of Coronavirus 2019 (COVID-19) pneumonia with other pneumonias. Clin Infect Dis 2020;71:756-61. https://doi.org/10.1093/cid/ciaa247

14. Lei S, Jiang F, Su W, Chen C, Chen J, Mei W, et al. Clinical characteristics and outcomes of patients undergoing surgeries during the incubation period of COVID-19 infection. EClinicalMedicine 2020;21:100331. https://doi.org/10.1016/j.eclinm.2020.100331

15. Fattouch K, Corrao S, Augugliaro E, Minacapelli A, Nogara A, Zambelli G, et al. Cardiac surgery outcomes in patients with coronavirus disease 2019 (COVID-19): A case-series report [published online ahead of print, 2020 Oct 22]. J Thorac Cardiovasc Surg. 2020;S00225223(20)32872-5. https://doi.org/10.1016/j.jtcvs.2020.09.138 